\title{
Patient Satisfaction, Trust and Commitment: Mediator of Service Quality and Its Impact on Loyalty (An Empirical Study in Southeast Sulawesi Public Hospitals)
}

\author{
Patawayati $^{1}$, Djumilah Zain ${ }^{2}$, Margono Setiawan ${ }^{2}$ and Mintarti Rahayu ${ }^{2}$ \\ ${ }^{1}$ (Doctoral Program of Management Science, Faculty of Business and Economics in Brawijaya University \\ Malang East Java of Indonesia) \\ ${ }^{2}$ (Department of Management, Faculty of Business and Economics in Brawijaya University, Malang East Java \\ of Indonesia)
}

\begin{abstract}
The purpose of this paper is to conceptualize hospital service quality into its component indicators from the perspectives of patients. More specifically, this research aims to test and explain empirically the mediators of relationship between patient satisfaction, trust, commitment and loyalty in public hospitals Southeast Sulawesi of Indonesia. The study employs questionnaire-survey approach to obtain the perceptions of patients. The instruments developed have been validated using tests for reliability, validity and unitdimensionality. The data were analyzed using structural equation modeling. The results indicate that service quality has positive and significant effects on patient satisfaction, and patients trust and commitment significantly affect patient's loyalty. However, the patient satisfaction has no significant effect on patient's loyalty. In addition, patient trust and commitment is positively affected by patient satisfaction. Further, this research can prove an increase in patient satisfaction capable improve patient loyalty through the mediating role of patient trust and commitment (complete mediation), but patient satisfaction did not mediate the relationship between service quality toward patient loyalty. Finally, high level of patient commitment proved to be an partial mediator the relationship between trust toward patient loyalty. Originality of this study conceptualizes hospital service quality as an five-indicators framework. Further, it also presents integrated model the relationship between service quality, patient satisfaction and loyalty, with patient trust and commitment as the mediators in public hospitals of Southeast Sulawesi province.
\end{abstract}

Keywords: Commitment, Loyalty, Satisfaction, Service Quality, Trust.

\section{Introduction}

As the importance of service quality, as both a marketing strategy and competitive advantage, gains more and more recognition from poor service delivery are receiving increased attention in extant literature [1]. Yet, much of the literature, is based on anecdotal accounts rather than theoretical conceptualizations or rigorous empirical assessment. If allowed to continue, poor service delivery threatens the long-term survival of the organization [2]. As with the healthcare delivery systems in developing countries where the resources are not in proportion to the demands placed on services of healthcare institutions, and where the possibility of resources being increased in the short term is quite different, calls for the increase in the effectiveness of the healthcare system by the efficient management of hospitals. Hospitals in developing countries absorb more resources than any other kind of recurrent government spending on health. A review of the health sector in many countries suggests that these large recurrent expenditures on hospitals involve a great waste of resources because of the technical and managerial inefficiency within hospitals [3]. Hence, delivering quality service becomes vital.

The Ministry of Health $(\mathrm{MOH})$ is the major healthcare provider in Southeast Sulawesi of Indonesia, although the service is also being complemented by the private sector which constitutes about $49,43 \%$ of overall healthcare services. Public hospitals in the country are organized into national level, provinces level and district level. The provinces level hospital is public hospital in Southeast Sulawesi, which serves as the provinces referral centre. It is the largest hospital in the Southeast Sulawesi province with 259 beds, providing a comprehensive range of tertiary care services. The provinces level hospitals provide a comprehensive range of secondary care services and are located in the provinces capital of each of the thirty-three province in the country. Health development is an attempt to meet the people's basic rights, to obtain quality healthcare. Reality happens that health conditions in Indonesia is still very poor and is characterized by the number of malnourished children under five that reached 2.3 million people. Seeing this condition of health care issues still need to be one of the priorities in national and regional development. In an effort to improve the quality of health care, it turns out some of the problems and challenges emerging as a result of socio-economic changes and changes in the global strategic environment and national. 
Ironically phenomenon based on public hospital performance indicators are Bed Occupancy Rate (BOR) or percentage that shows the average bed that is used every day, still below the standards that should be achieved. Rate BOR achieved public hospitals in Indonesia today is still ranging between 50\%. Though the ideal standard of value that should be achieved by referring to the standard MOH are 70-85\%. Another phenomenon that there are still many customers complain or patients who experience a less than satisfactory service quality. This happens because the doctors and nurses in providing information to patients is still very low associated with the disease, the lack of information led to patient dissatisfaction. The complaint most crucial in Southeast Sulawesi Province public hospital is a hospital which accommodates a very limited number of patients, especially the bed, it resulted in a queue of patients accumulate mainly in the emergency department to be hospitalized. The number of patients queuing the room is written caregivers can reach 5-10 numbers. Other empirical facts that occurred when assessed from average length of stay or the average duration of admission, which ideally 7-10 days hospitalized, had to be shortened to 4-5 days.

Theoretical study that became the basis for assessing and measuring the relationship between variables in this study refers to the concept of relationship marketing is a marketing philosophy that focuses on maintaining long-term relationships with existing customers. The assumption underlying the concept of relationship marketing thinking is the final consumer or business customers prefer to establish a sustainable relationship with the organization from the customer's need changing in order to get the expected value. The application of the concept of relationship marketing provides several benefits to the company and the customer. The benefits derived are customers "confidence benefits, social benefits and treatment benefits" [4]. Suggested that customer satisfaction can be built through the quality of goods/services, customer service and value [5]. This shows the quality of service is a variable that affects customer satisfaction. Customer satisfaction is the best guarantee for creating and maintaining customer trust seta defenses to face global competition. Creating a superior quality of service to be supported human resources that are reliable and adequate technology.

The success of the hospital to maintain customer loyalty is influenced by many factors including: the quality of the service, either directly or mediated by an increasing role of trust, commitment and customer satisfaction. The pursuit of quality of service becomes an important factor for any business that is driven by the need to remain competitive [6]. Furthermore, the quality of service is antecedents customer satisfaction and loyalty $[6,7,8]$. The high level of service performance is believed to be an effective way to improve customer satisfaction, trust, and loyalty $[9,10,11]$ find a high quality of service actually able to increase customer satisfaction, supported by research as well $[12,13,14,20]$. Furthermore, service quality not only directly significant effect on customer satisfaction but also on customer loyalty and trust. These results indicate a significant effect on the quality of service satisfaction and customer trust $[16,16]$ and a significant effect on customer loyalty $[17,18,19]$. In contrast to results of studies [3] that there are some dimensions of service quality does not significantly influence patient satisfaction. There are gaps findings influence the quality of service to the loyalty due to variability in the measurement indicators, examined the object and the basic theory is used so that this important research to be done to test the contradictory findings of previous research.

The empirical studies cited above most researchers have shown a good quality of direct service to increase customer satisfaction. Theoretically [5] stated that the quality of service should start from the needs of the customer, then the impact on customer satisfaction with the latest on customer loyalty. This means that good quality care is expected to increase customer satisfaction, and high customer satisfaction can generate customer loyalty. But it turns out empirically the relationship between customer satisfaction and customer loyalty is very diverse, which is the first, the researchers proved that satisfaction has positive and significant impact on customer loyalty $[20,21,22,24]$. On the other hand, there are findings that overall customer satisfaction and satisfaction are positive and significant technique to loyalty [23,24]. On the other hand, there are findings that satisfaction and no significant negative effect on customer loyalty [25]. The results [23] find satisfaction variables are not functionally significant effect on customer loyalty. Second, the results of previous studies that prove that the quality of service does not directly influence the loyalty, but mediated by customer satisfaction $[11,26,27]$. Then mediation customer satisfaction relationship quality service to the customer's trust $[15,16]$. Further significant satisfaction as mediating the relationship between the quality of customer service commitment $[12,28]$. Third, other studies prove that customer satisfaction does not directly influence customer loyalty, but customer trust mediated $[14,15,29,30]$. Then the role of customer trust directly have a positive and significant impact on customer loyalty $[14,15,30,31]$. While the research findings $[16,29,32,33]$ proved that the trust had no significant effect on customer loyalty. Deliberate the findings of [33] occurred because of the trust should be built on the basis of long-term relations with customers so that customers trust the new no significant effect on customer loyalty. Finally, the findings of studies that prove that customer satisfaction does not directly influence the loyalty, but mediated by customer commitment [12,28,29]. Research occurs directly influence customer satisfaction and significant positive customer commitment [12,28,31]. Should the findings of [13] proved positive and significant commitment to customer satisfaction. The difference in results [29] occurs due 
to increased customer satisfaction and trust is not accompanied by an increase in higher customer commitment, but the intention to behave customers need to be reviewed and recommend to potential customers.

Gaps previous studies on the effects of service quality on customer satisfaction. Then the customer satisfaction with trust, commitment and loyalty gap obtained important and interesting to study further so that the motivation in this study as follows: first, the variability model of the relationship between satisfaction and loyalty indicating a direct relationship between satisfaction and loyalty can't be valid in general objects very different. Hence each object further research is needed in order to know the exact form of the model the relationship between customer satisfaction and loyalty. Second, this study fashion design relationship between satisfaction and loyalty are more integrated with mediation include two variables (trust and commitment) that has been used previously researchers separately [28,29,31]. Reform can study sought to discover how the war of each behavior is detected as a mediating variable between satisfaction to loyalty particularly in health services in the Hospital of Southeast Sulawesi province. Third, examination of satisfaction, trust, and commitment to customer loyalty customers there are contradictions caused by the diversity of variables measuring dimensions of customer loyalty. Fourth, previous research conducted on the quality of service to satisfaction, trust and loyalty commitment is still inconclusive evidence that is needed in order generalization on services especially in health fishermen Hospital of Southeast Sulawesi province.

Based on the theoretical and the reality of what happened there is still a gap of research on the influence of service quality on satisfaction, trust, commitment and loyalty of patients. The key problem in this research is questioning the variable satisfaction, trust and commitment influence patient loyalty and the role of trust and commitment as a mediating variable in the public hospital of Southeast Sulawesi province. While the objectives are to test and explain empirically effect on satisfaction of service quality and patient satisfaction directly affect the confidence, commitment and loyalty. In addition to test and explain empirically indirect effect of service quality to loyalty mediated patient satisfaction and contentment does not directly influence service loyalty, patient satisfaction, trust and commitment to patients. Theoretically, the research findings are expected to be useful to establish a marketing management science, especially some of the variables in consumer behavior and marketing services comprising variable service quality, patient satisfaction, trust, commitment toward patient loyalty. Besides the practical benefits that can contribute to the organization of government, in particular public hospital Southeast Sulawesi province in providing service quality, satisfaction and loyalty to the patient and for information and reference for other researchers in the field of service marketing research and consumer behavior, particularly in relation to the variable service quality, patient satisfaction, trust, commitment toward patient loyalty.

\section{Literature Review, Hypotheses and Conceptual Framework 2.1 Relationship Service quality and patient satisfaction}

The conceptual definition of service quality developed by [34] has been largely employed for comparing excellence in the service encounters by customers [35]. Defined service quality as the customers' overall impression of the relative inferiority/superiority of a service provider and its services and is often considered similar to the customer's overall attitude towards the company [34,36]. This definition of service quality covers several points. One of them is an attitude developed over all previous encounters with a service firm [34,36,37] defined service quality as an attitude of the consumer relating to the results from comparisons between expectations of service with his perceptions of actual performance.

The most widely reported set of service quality was offered by [34,37], who condensed using factor analysis the dimensions of service quality into five categories: tangibles (facilities, equipment and appearance of staff); reliability (ability to perform the promised service dependably and accurately); responsiveness (willingness to help customers and provide prompt service); assurance (knowledge and courtesy of staff and their ability to convey trust and confidence); and empathy (caring, individualized attention the organization provides to its customers). [38] also differentiated service quality dimensions in core aspects of the service (reliability), which are mainly concerned with the outcome of service and process aspects of the service (tangibles, responsiveness, assurance and empathy), which are related with the service delivery process. Service means an intangible activity or benefit provided by the services provider to customer, which can be tangible product and something that is added to intangible service, or in an independent form [39]. With regard to the nature of service, there exist some different opinions among the researchers, but service is known to have four properties; being intangible, inseparability of production and consumption, heterogeneity, and perish ability [37]. The concept of service quality can be represented in different way depending on aspect and approaching method. Especially, service quality has a aspect emphasized by subjective assessment recognized by each individual customer rather than that examined objectively being difficult to measure owing to its specialty.

Generally, the definition of quality varies depending on the methods of approach driven to transcendental experience, product, manufacture, value, and user [40]. In today's highly competitive healthcare environment, hospitals, like all other public or private organizations and institutions, are confronted with the 
necessity of measuring both their financial (costs, revenues, profitability) and non financial performance (quality of their services), in order to improve their functions and increase their competitiveness. Performance measurement is not an easy task in health services, where a wide range of stakeholders is involved. [41] suggests eight essentials of performance measurement, including service quality. The service quality literature in the context of hospitals has mostly focused on patient's and management's perspective, so far. Some of the studies investigated the gaps between the service providers' perceptions and patients' perceptions. Healthcare services, being high in credence qualities, cognitive judgment will not prevail in the patient's evaluation of service delivery.

Further, in a hospital environment, patients are in a state of physiological or psychological discomfort [42]. Thus, they require the assistance of others to interact with the service providers. In Southeast Sulawesi of Indonesia, an in-patient is always accompanied by an attendant. So, it is often these attendants who are in a good position to judge the care provided. A holistic picture of healthcare services that focuses on the attendants' needs, while providing hospital services will be extremely useful to healthcare service providers. Hence, this study aims to conceptualize service quality from the perspective of patients. Service quality and satisfaction have been considered as two sides of the same coin. [43] proposed that satisfaction is a function of the disconfirmation of performance from expectation. While there is debate in the literature about the antecedent relationship of service quality and satisfaction, it is generally agreed that service quality drives satisfaction $[35,43,60,61]$. The basis of this perspective is attributed to the appraisal, emotional response (affect), coping framework of $[44,63]$ which suggests that service quality, as a cognitive appraisal, leads to an emotive assessment of satisfaction. This study proposes the following assumptions:

\section{H1. Service quality will positively impact the degree of patient satisfaction.}

\subsection{Relationship Patient Satisfaction, Trust, Commitment and Loyalty}

Satisfaction is the consumer's fulfillment response [45]. It is a judgment that a product or service feature, or the product or service itself, provided (or is providing) a pleasurable level of consumption-related fulfillment, and includes levels of under or over fulfillment [46,62]. From the above definitions, it is understood that satisfaction relates to a subjective evaluation of emotions. Satisfaction occurs as a function of disconfirmation and relative output to input. The end-result is a positive or negative feeling of fulfillment. Relationship quality, including trust and commitment, has been evaluated differently by various researchers, with some having taken it to be an antecedent of overall satisfaction [15,64], some giving trust and customer satisfaction an equal footing [29,63] and others taking relationship quality and service quality together to be antecedents of behavioral intentions $[29,47]$. [40,64] on reviewing the literature, assert relationship quality to be a consequence of customer satisfaction as well as service encounter. This study adopted the [40] posterior perception of relationship quality, which develops after the customer is served and is continuously altered with subsequent service encounters in a cumulative fashion [12]. In their relationship model, [49] consider an association between trust and loyalty, although their results showed no statistically significant relationship. Similarly, [42] consider trust as an antecedent to loyalty, at the same level as satisfaction. For [50] trust and satisfaction influence loyalty. This argument was subjected to empirical testing through the following hypothesis:

\section{H2. Patient satisfaction has a significant positive effect on trust. \\ H3. Patient trust has a significant positive impact on loyalty.}

Commitment is a customer's long term orientation towards a business relationship [1,52,62]. This orientation is based on emotional bonds $[18,52]$ as well as an expectation of higher benefits by staying in the relationship [12]. Committed customers experience relationship closeness [15], which over time enhances client loyalty [52]. Customer commitment has suffered a conceptual misplacement in research when it has been viewed as an antecedent to satisfaction [24,63] or has simply been left out of models. On this point, reference [52] "ongoing" and "maintenance" definitional keywords, which imply the posteriori placement of commitment to customer satisfaction rather than its priority to satisfaction.

The literature offers several models suggesting that commitment drives attitudinal loyalty [11,20], referrals [17] and behavioral intentions [14]. Researchers have also linked commitment directly to word of mouth and willingness to recommend [14,26,28]. Numerous studies have found commitment to have a positive influence on satisfaction [13]. Consequently we posit commitment as an antecedent of relationship outcomes [10]. The relationship between commitment and loyalty has also been considered [49] detecting a significant and positive association. Likewise, for [50,35] commitment appears as an antecedent to loyalty. Different authors distinguish an affective component in commitment as against a more normative or rational one. For [13] it is precisely the affective component which is linked to loyalty.

Customer commitment is recognized as being crucial to long-term relationships [44,52]. In fact, commitment has long been regarded as a critical variable in successful social exchanges [53], including customer-provider relationships [52]. Committed customers are more likely to remain loyal to the service firm 
[28] as they feel that the service relationship is important [33]. As a result, they have a desire to maintain the relationship while also being willing to put effort into maintaining the relationship [52]. As customers and firms become more committed to each other, the client-firm relationship becomes more stable [13], thus fostering a long-term relationship. As business becomes increasingly competitive, creating and sustaining customer loyalty is critical [28]. Loyalty is important because it positively impacts sales, share-of-wallet and customer retention $[13,28,33]$. Increased loyalty translates into higher profits because it is less expensive to retain customers than to attract new ones [23,47,62]. As suggested [51], loyalty provides a concrete outcome against which relationships can be measured. While commitment has been shown to positively predict aspects of customer loyalty, such as referrals, the relationship between commitment and loyalty has not received substantial research attention [28]. Customers that are committed to a firm will hold the relationship in high regard, believing that the relationship deserves effort and attention. Commitment signifies a long-term relational perspective [33] and encourages exchange parties to resist the short-term benefits offered by other firms in favor of the benefits associated with remaining in a relationship [52]. Mutual commitment creates the foundation upon which relationships are built [38]. Consequently, we proposed the following hypothesis to test the relationship:

\section{H4. Patient satisfaction has a significant positive impact on commitment.}

H5. Patient commitment has a significant positive effect on loyalty.

Satisfaction is defined as an emotional state resulting from a customer's interactions with a service provider over time [29]. [43] defined satisfaction as a function of a cognitive comparison of expectations prior to consumption with the actual experience. This process is often referred to as the disconfirmation paradigm, whereby customers make a post-purchase comparison between repurchase expectations and actual performance received [45]. When actual performance exceeds expectations, positive disconfirmation occurs and leads to satisfaction, while actual performance below expectations results in negative disconfirmation and dissatisfaction. Two conceptualizations of satisfaction can be distinguished: transaction-specific and cumulative satisfaction [50]. A common approach in defining customer loyalty is to distinguish between a consumer's behavioral loyalty and attitudinal loyalty $[38,40]$. Behavioral loyalty is expressed as repeated transactions (or percentage of total transactions in the category, or total expenditures in the category) and can sometimes be measured quite simply with observational techniques. Attitudinal loyalty is often defined as positive affect toward both continuance of the relationship and the desire to remain in the relationship, and is sometimes defined as equivalent to relationship commitment [14,20,21,52]. We may consider both affective and co native loyalty to be kinds of attitudinal loyalty. Strong attitudinal loyalty makes customers more resistant to attempts by other marketers to steal them away [15] and more resistant to counter-persuasion or to searching for alternatives.

Loyalty and satisfaction are related, although also clearly distinct. [1,40], in their studies, consider several conceptual bases for this distinction, but, in general, higher satisfaction has been proposed to be related to higher loyalty. As has been hypothesized and borne out in the marketing literature $[10,14,21,52,63]$, trust is logically and experientially a critical variable in relationships. Those who are not willing to trust a vendor in a competitive marketplace are unlikely to be loyal. The importance of trust in explaining loyalty is also supported $[12,29,30]$. Trust is sometimes conceived of, as pointed out [15], as having two components: performance or credibility trust and benevolence trust. In a business-to-business context, [15] found strong effects for credibility trust on relationship commitment but not for benevolence trust. He argued that this was because businesses base their purchase and selling decisions much more on performance issues. Clearly, performance or credibility trust is important in business-to-consumer relationships as well. Other authors have also suggested the existence of an effect for credibility trust on loyalty $[1,10,63]$. Evaluation of cumulative satisfaction is based on the firm's past, current, and future service performance. In contrast, transaction-specific satisfaction may provide specific diagnostic information about a particular service performance. Numerous studies in the service marketing literature have hypothesized and validated empirically the relationship between satisfaction and customer loyalty such as customer referrals, purchase intentions, usage of a service, share of wallet, and retention $[10,15,28,30,43]$. In line with previous research, it is hypothesized that:

\section{H6. Patient satisfaction has a significant positive impact toward loyalty.}

Trust and commitment are not independent concepts, they are interrelated. The existence of a direct positive link from trust to commitment has been widely justified in the literature. Most studies have configured trust as a major determinant of commitment [40,52], however, a few authors have considered trust and commitment to be the main dimensions of a higher order construct named "relationship quality" representing the overall assessment of the relationship [12]. Research on relationship quality is quite recent, and although trust and commitment are often included in the construct, the different studies have not systematically examined the measure of the construct and have proposed different dimensions [31]. As trust is considered an effective and desirable attribute in long-term relationships between organizations [28], when an organization perceives that there is trust in a relationship; it will want to commit to it. Consequently, a high level of commitment will contribute to stabilize the relationship. Moreover, according to [52,62], as commitment implies vulnerability, 
organizations will only seek partners they can trust. Therefore, it is unlikely that one of the parties in a relationship can be committed to the other without a basis of trust in the relationship, and this is the basis for our next hypothesis:

\section{H7. Patient trust has a significant positive impact toward commitment}

Given our interest in the role of service quality in public hospitals service relationships we adopt the position that service quality is likely to mediate the relationship between service quality, trust and commitment. Patients differentiate between service hospitals on the basis of service quality [40,43,52]. Research has demonstrated a significant positive relationship between satisfaction and loyalty $[15,29,30]$ and between trust and loyalty $[14,30,33]$. While the association between commitment and customer loyalty has received considerably less research attention than that between satisfaction and trust $[16,61]$ we posit commitment as an important driver of customer loyalty.

We further suggest that the relationship between these constructs is complex, with customer experience moderating the salience of these associations. Given that satisfaction is likely to be felt immediately where as trust and commitment are likely to be built up with time and encounters, we believe that novice customers are likely to rely more heavily on satisfaction judgments in developing loyalty than more experienced customers. In contrast, the cumulative, the longer-term nature of trust and commitment suggests that for more experienced customers these constructs may have a greater impact on loyalty than they do for novice customers. Finally, the association between satisfaction and loyalty has been analyzed in several works $[16,23,24,26,60]$. [49] consider the relationship between satisfaction and loyalty, where loyalty and find a significant and positive relationship. Thus we hypothesize that:

H8. Patient satisfaction is a mediator of the relationship between the service quality on patient loyalty H9. Patient trust is a mediator of the relationship between the satisfaction on patient loyalty H10. Patient commitment is a mediator of the relationship between the satisfaction on patient loyalty H11. Patient commitment is a mediator of the relationship between the trust on patient loyalty

The conceptual framework shown in Figure 1 outlines the proposed relationships between service quality, patient satisfaction and relationship quality (trust and commitment) were integrated into the model to explain the formation of patient loyalty clearly.

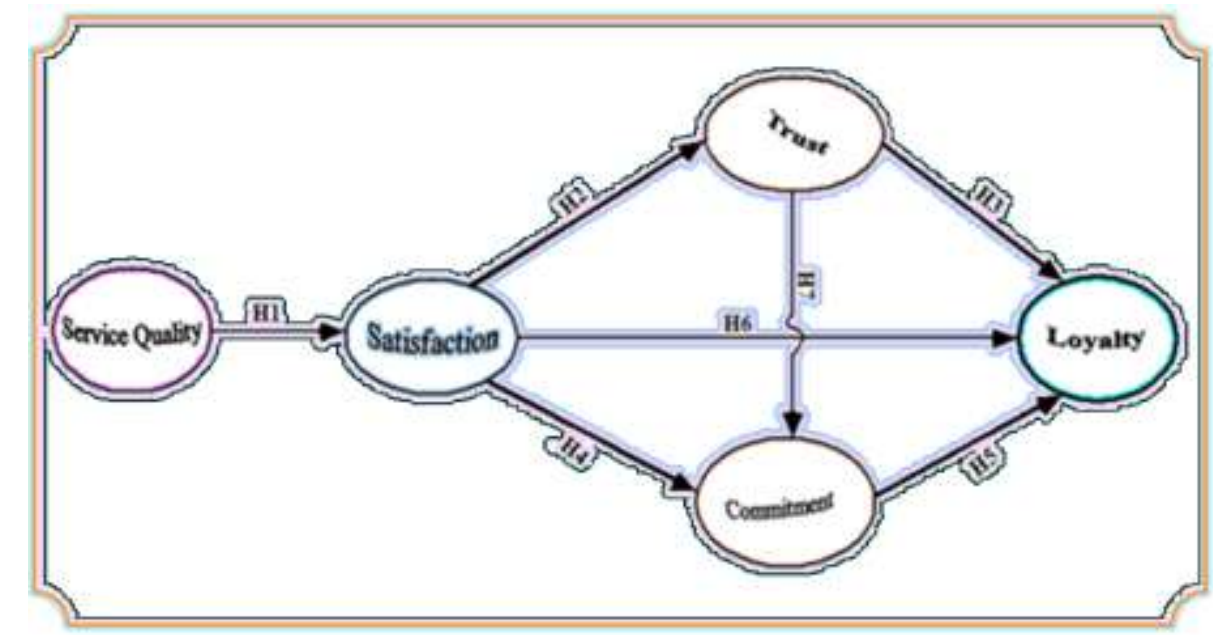

Figure 1. The research model and hypotheses

\subsection{Data collection and sampling}

\section{Research Methods}

The importance of public hospital in Southeast Sulawesi province investigating the causes the low of service quality and developing recovery strategies that meet patients expectations of how the management hospital should handle such problems is emphasized in extant literature. Thus the design of this research used explanatory research approach in order to explain the relationship between variables by testing hypotheses and draw conclusions that are of quality. The unit of analysis in this study were patients who have used services in the public Hospital of Southeast Sulawesi province. The population in this study were all patients hospitalized in the last two months in public hospital of Southeast Sulawesi province. Convenience sampling was chosen over random sampling due to practical reasons. For example, during the pilot test, a patient who suffered from depression who was randomly selected according to bed number, cried and cried throughout the time the researcher was with her. Some patients simply refused to participate. Given the situation, both surveys had to be conducted purely on a voluntary basis. 
A self-completion questionnaire was used as the main primary data collection method. The questionnaire used in the research survey was highly structured where most of its questions were fixed-response alternative questions that required the respondents to select from responses which are located by using five point Likert scales ranging from 5 (strongly agree) to 1 (strongly disagree) [56,54]. The type of research is a single cross-sectional design in which the collection of data from the research respondents (patients) was carried out only once. Multiple item measures of each construct were used to capture its richness and attributes. Our instrument was piloted using personal interviews with patients and key directors/managers in the public hospital reveal ability of patients (respondents) to understand it and to test its appropriateness for research purposes. Using a team of researchers, the primary data collection was carried out using the "personal delivery" approach which usually yields a high response rate. The questionnaires were personally delivered to the respondents and were collected after one weeks. In the main survey, we delivered 200 questionnaires to a patient adult patients hospitalized for 6 days and a minimum of a patient's condition that is not possible, be replaced by a family member who is able to provide relevant information in public hospital Southeast Sulawesi province from which 165 were returned; the response rate was 82.5 percent. The valid and useable questionnaires for data analysis were 150 (90.90 percent from the returned questionnaires).

\subsection{Analytical methods}

The present study used the Statistical Package for Social Sciences (SPSS) for descriptive and inferential analyses (e.g. sampling profile, correlation). To test the proposed relationships among the study variables, structural equation modeling (SEM) was conducted using the AMOS 16.0 program. As suggested by [55], construct validity was assessed by running a confirmatory factor analysis (CFA) before testing the hypothesized paths using the SEM. The mediating roles of satisfaction, trust, and commitment were tested by examining the direct and indirect effects of these constructs' predictors on patient loyalty. The reasons selection method of Structural Equation Modeling with using AMOS program (Analysis Moment of Structural) as follows: (1) a model the conceptual framework of this study, a pattern of a causal relationship between the service quality effects patient satisfaction and patient satisfaction directly affects the trust, commitment and patient loyalty. Patient satisfaction was also hypothesized to influence patient loyalty through the mediation of trust and commitment, many relationships and hierarchical nature of the relationship in this study can only be solved with the help of structural methods; (2) This study uses latent variable measured by the indicators. SEM suitable for confirming unit-dimensionality of indicators for a constructs, (3) variance-based SEM with AMOS method is one of the multivariate analysis techniques can do a series of analysis of some latent variables simultaneously, thus providing statistical efficiency, (4) The SEM analytical approach combines factor analysis, structural models, and path analysis.

\section{Results}

Table 1. depicts the demographic profile for the sample, which is reasonably balanced by gender and is well spread over age, profession, education groups, type of treatments and source of treatment costs. For the analysis of patient attitudes SPSS software was used. According to the descriptive statistics that were generated, overall patient satisfaction (mean $=3.14)$; patient commitment (mean $=3.44)$; patient loyalty (mean $=3.36$ ) and patient trust (mean $=3.62$ ) is high and all the mean scores for the ten statements related to service quality indicators were above the median value of 3 (see Table 2). Furthermore, there are strong attitudes towards the service quality indicators offered by the public hospital's of Southeast Sulawesi province. Specifically, tangible (3.74), reliability (3.82), responsiveness (3.82), assurance (3.94) and empathy (3.45).

Table 1. Respondents profile

\begin{tabular}{llcc}
\hline & & \multicolumn{2}{c}{ Sample demographics } \\
\cline { 3 - 4 } Gender & Male & Frequency & Percent \\
& Female & 69 & 46 \\
& $\leq 20$ & 81 & 54 \\
& $21-30$ & 9 & 6 \\
& $31-40$ & 22 & 14.67 \\
Profession & $41-50$ & 32 & 21.33 \\
& $51+$ & 31 & 20.67 \\
& Servants Civil (PNS) & 56 & 37.33 \\
& Private employees & 67 & 44.67 \\
& Members of TNI / Police & 15 & 10 \\
& Entrepreneur & 5 & 3.33 \\
& Other & 40 & 26.67 \\
& & 23 & 15.33
\end{tabular}




\begin{tabular}{llcc} 
Education & Elementary school & 3 & 2 \\
& Secondary education first & 20 & 13.33 \\
& High school & 76 & 50.67 \\
& Diploma & 23 & 15.33 \\
Type of treatments & University & 28 & 18.67 \\
& Outpatient & 44 & 29.33 \\
& Hospitalization & 32 & 21.33 \\
Source of Treatment & Outpatient and Hospitalization & 56 & 37.33 \\
Costs & Never (new patients) & 18 & 12 \\
& Own & 29 & 19.33 \\
& Company/Institution work & 19 & 12.67 \\
& Access /Social Security/Astek & 59 & 39.33 \\
& Askeskin program /Jamkesmas /Bahteramas & 31 & 20.67 \\
\hline
\end{tabular}

Notes: $\mathrm{n}=150$

Table 2. Mean, Loading Factor and Reliability Analysis of Measurement Scales

\begin{tabular}{|c|c|c|c|c|c|}
\hline Construct/Indicators & Mean & $\begin{array}{l}\text { Loading } \\
\text { factor }\end{array}$ & $\begin{array}{c}\text { Cronbach } \\
\text { alpha }\end{array}$ & CR & AVE \\
\hline Service quality (SQ): & 3.75 & & 0.888 & 0.992 & 0.960 \\
\hline $\mathrm{SQ}_{1}$. Tangibles & 3.74 & $0.900 *$ & & & \\
\hline $\mathrm{SQ}_{2}$. Reliability & 3.82 & $0.919 *$ & & & \\
\hline $\mathrm{SQ}_{3}$. Responsiveness & 3.82 & $0.907 *$ & & & \\
\hline $\mathrm{SQ}_{4}$. Assurance & 3.94 & $0.702 *$ & & & \\
\hline $\mathrm{SQ}_{5}$. Empathy & 3.45 & $0.849 *$ & & & \\
\hline Patient Satisfaction (PS): & 3.14 & & 0.948 & 0.990 & 0.951 \\
\hline $\mathrm{PS}_{1}$. Satisfaction toward nursing services & 3.07 & $0.885^{*}$ & & & \\
\hline $\mathrm{PS}_{2}$. Satisfaction toward the diagnosis & 3.11 & $0.935^{*}$ & & & \\
\hline $\mathrm{PS}_{3}$. Satisfaction toward clinical investigations & 3.20 & $0.931 *$ & & & \\
\hline $\mathrm{PS}_{4}$. Satisfaction toward the services prescribed & 3.23 & $0.886^{*}$ & & & \\
\hline $\mathrm{PS}_{5}$. Happiness toward the information & 3.11 & $0.906^{*}$ & & & \\
\hline Patient Trust (PT): & 3.62 & & 0.774 & 0.970 & 0.916 \\
\hline $\mathrm{PT}_{1}$. Honesty & 3.39 & $0.667 *$ & & & \\
\hline $\mathrm{PT}_{2}$. Credibility & 3.82 & $0.846^{*}$ & & & \\
\hline $\mathrm{PT}_{3}$. Benevolence & 3.66 & $0.920 *$ & & & \\
\hline Patient Commitment (PC): & 3.44 & & 0.789 & 0.991 & 0.956 \\
\hline $\mathrm{PC}_{1}$. Maintain the relationship & 3.48 & $0.889 *$ & & & \\
\hline $\mathrm{PC}_{2}$. Very important to me & 3.27 & $0.859 *$ & & & \\
\hline $\mathrm{PC}_{3}$. Deserves my maximum effort to maintain & 3.52 & $0.903^{*}$ & & & \\
\hline $\mathrm{PC}_{4}$. Relationship that I have & 3.47 & $0.922 *$ & & & \\
\hline $\mathrm{PC}_{5}$. Very proud & 3.47 & $0.862 *$ & & & \\
\hline Patient Loyalty (PL): & 3.36 & & 0.813 & 0.974 & 0.950 \\
\hline $\mathrm{PL}_{1}$. Word-of-Mouth & 3.28 & $0.837 *$ & & & \\
\hline $\mathrm{PL}_{2 .}$ Patients complaints & 3.43 & $0.900 *$ & & & \\
\hline
\end{tabular}

Notes: Cronbach alpha (Acc. value >0.70); AVE/Variance extracted (Acc. value >0.50); CR/Composite reliability (Acc. value $>0.70$ ); Significance at: $* p<0.05$.

For the scales' reliability analysis, Cronbach's alpha, average variance extracted (AVE) and composite reliability (CR) were calculated for all latent variables' measurement scales. Results, as seen in Table 2, revealed that all scales were reliable. Additional evidence provided by or derived from the CFA suggests that the resulting measures are reliable and valid as indicated by the relatively high composite reliability (CR) and average variances extracted (AVE), as shown in Table 2 [55]. Convergent validity to establish the convergent validity, the items of specific construct should share a high proportion of variances in common. As can be seen in Table 2, the convergent validity is indicated by: (1) All factor loadings are significant; the relatively high $\mathrm{AVE}$ (SQ $=96$ percent, $\mathrm{PS}=95$ percent, $\mathrm{PT}=92$ percent, $\mathrm{PC}=96$ percent, and $\mathrm{PL}=95$ percent). CR is higher than 0.7. ( $\mathrm{SQ}=0.99, \mathrm{PS}=0.99, \mathrm{PT}=0.97, \mathrm{PC}=0.99$ and $\mathrm{PL}=0.97)$ provide evidence in support of the measures' reliability. For the appropriate "goodness of fit" test, structural equation modeling (SEM) analysis was performed using the "Amos 16.0" software. SEM, which is a multivariate technique, was chosen for this study because it is able to analyze the relations between both unobservable (latent) and observable variables and test the validity of a causal structure.

This study uses the AMOS version 16.0 to verify the structural equation modeling (SEM) and uses the maximum likelihood to analyze the theoretical models for goodness of fit. The use of SEM estimates the effects simultaneously and is thus more true to the simultaneous nature of the impact of these variables in the research 
model. It also allows for convenient estimation of the effects of individual predictors [55]. The measurement model relates the observed and unobserved variables that justify the use of the latter in estimating the former [57]. The estimation of the measurement model through confirmatory factor analysis (CFA) is a prerequisite in validating the structural model that is of interest in a piece of research. Upon subjection of the measurement items to CFA (see Table 2), the chi-square value $(\chi 2)$ of $187.501(\mathrm{df}=163, \mathrm{p}<0,001)$ was obtained, indicating the goodness-of-fit. Furthermore, the $\chi^{2} / \mathrm{df}$ ratio was 1.150 , which enhances the acceptability of the model as it is within the acceptable range of $\leq 2,00$ [55]. Other fit parameters (see Table 3) of the comparative fit index (CFI $=0.983)$ and nor med fit index $(\mathrm{NFI}=0.980)$ is higher than the accepted standard value of 0.90 ; as well as the root mean square of approximation (RMSEA $=0.045$ ) is lower than the accepted standard value range of 0.08 ; the mean residual square root of RMR $=0.02$ ) is lower than the acceptable standard value 0.05 . a value close to 0 suggests a better goodness of fit. Overall, we found that the model had an acceptable goodness of fit. Using the "model building technique", the model was finalized by including in the independent model the proposed modification indices paths. According to the results, as presented in Table 3, all the important indicators of the model fit, as suggested [55], are above the accepted values. For this reason this model is considered as an acceptable one (Figure 2).

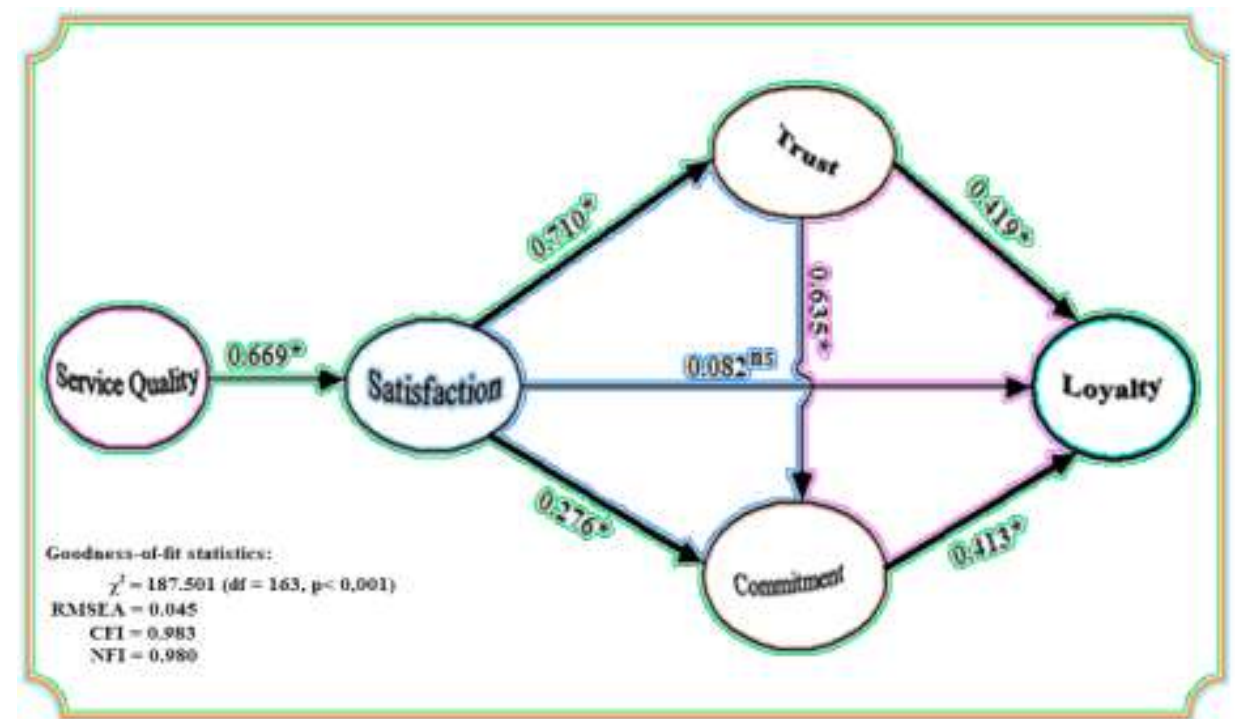

Notes: Significance at: ${ }^{*} \rho<0.05 ;$ ns $=$ not significant

Figure 2. Results of the structural model

Table 2. Results of standardized regression weights for the model

\begin{tabular}{|c|c|c|c|c|c|c|c|c|c|}
\hline \multicolumn{5}{|c|}{ The relationships between variables } & \multirow[t]{2}{*}{$\begin{array}{c}\text { Standardized } \\
\text { estimate } \\
\end{array}$} & $\begin{array}{c}\text { C.R/ } \\
\text { t-value }\end{array}$ & P-value & \multicolumn{2}{|c|}{ Result } \\
\hline \multicolumn{9}{|c|}{ Hypothesized path Direct effects: } & \\
\hline H1. & Service quality & $->P$ & tient satisfactio & & 0,669 & 6,193 & $0.000^{*}$ & Significant & Accepted \\
\hline $\mathrm{H} 2$. & Patient satisfa & tion - & $>$ Patient trust & & 0.710 & 5.100 & $0.000^{*}$ & Significant & Accepted \\
\hline H3. & Patient trust --> & Patie & nt loyalty & & 0.419 & 2.167 & $0.030 *$ & Significant & Accepted \\
\hline $\mathrm{H} 4$. & Patient satisfac & ion -- & Patient commi & ment & 0.276 & 2.369 & $0.018^{*}$ & Significant & Accepted \\
\hline H5. & Patient commi & nent & -> Patient loyalt & & 0.413 & 2.081 & $0.037 *$ & Significant & Accepted \\
\hline H6. & Patient satisfac & ion -- & Patient loyalty & & 0.082 & 0.630 & 0.529 & $\begin{array}{c}\text { Not } \\
\text { Significant }\end{array}$ & Rejected \\
\hline H7. & Patient trust --> & Pati & nt commitment & & 0.635 & 4.247 & $0.000 *$ & Significant & Accepted \\
\hline \multicolumn{10}{|c|}{ Hypothesized path Indirect effects (mediating variable): } \\
\hline & Exogenous & & Mediation & Endogenous & $\begin{array}{l}\text { Standardized } \\
\text { estimate }\end{array}$ & & $\begin{array}{l}\text { ure of } \\
\text { liation }\end{array}$ & \multicolumn{2}{|c|}{ Result } \\
\hline H8. & $\begin{array}{l}\text { Service } \\
\text { quality }\end{array}$ & $-->$ & $\begin{array}{c}\text { Patient } \\
\text { satisfaction }\end{array}$ & --> Patient loyalty & 0.055 & \multicolumn{2}{|c|}{ Complete } & $\begin{array}{c}\text { Not } \\
\text { Significant }\end{array}$ & Rejected \\
\hline H9. & $\begin{array}{c}\text { Patient } \\
\text { satisfaction }\end{array}$ & & atient trust & --> Patient loyalty & $0.298 *$ & \multicolumn{2}{|c|}{ Complete } & Significant & Accepted \\
\hline H10. & $\begin{array}{c}\text { Patient } \\
\text { satisfaction }\end{array}$ & & $\begin{array}{c}\text { Patient } \\
\text { commitment }\end{array}$ & --> Patient loyalty & $0.114 *$ & \multicolumn{2}{|c|}{ Complete } & Significant & Accepted \\
\hline H11. & Patient trust & $-->$ & $\begin{array}{c}\text { Patient } \\
\text { commitment }\end{array}$ & --> Patient loyalty & $0.262 *$ & \multicolumn{2}{|c|}{ Partial } & Significant & Accepted \\
\hline \multicolumn{10}{|c|}{ Goodness-of-fit statistics: $\chi^{2}=187.501(\mathrm{df}=163, \mathrm{p}<0,001) ; \mathrm{RMSEA}=0.045 ; \mathrm{CFI}=0.983 ; \mathrm{NFI}=0.980$} \\
\hline
\end{tabular}


Notes: Significance at: $* \rho<0.05$

Having established the final structural equation model, it was possible to test the hypotheses developed for this study (see Figure 2 and Table 3). These hypotheses can be tested by evaluating the path coefficients and the significance levels among the constructs in the model. Analyzing the results showed that in the impact of service quality on patient satisfaction, service quality had a significant positive effect toward patient satisfaction $(\beta=0.669, \rho<0.05)$. From this, we see that H1 "service quality has a significant positive impact on patient satisfaction" is accepted. Thus, service quality has a significant positive impact toward patient satisfaction. Further, in the impact of patient satisfaction on trust, patient satisfaction has a significant positive effect on trust $(\beta=0.710, \rho<0.05)$. From this, we see that $\mathrm{H} 2$ "patient satisfaction has a significant positive impact on trust" is accepted. In the impact of patient satisfaction on commitment, patient satisfaction has a significant positive effect on commitment $(\beta=0.276, \rho<0.05)$. From this, we see that $\mathrm{H} 4$ "patient satisfaction has a significant positive impact on commitment" is accepted. Thus, patient satisfaction has a significant positive impact on relationship quality.

In the impact of patient trust on loyalty, patient trust has a significant positive effect on loyalty ( $\beta=$ $0.419, \rho<0.05$ ). From this, we can see that $\mathrm{H} 3$ "patient trust has a significant positive impact on loyalty" is true. Moreover, in the impact of patient commitment on loyalty, patient commitment has a significant positive effect on loyalty $(\beta=0.413, \rho<0.05)$. From this, we can see that H5 "patient commitment has a significant positive effect on loyalty." is true. Therefore, relationship quality has a significant positive impact on patient loyalty. The hypothesized impact of patient satisfaction on loyalty. Patient satisfaction no significant effect on loyalty ( $\beta=$ $0.082, \rho>0.05$ ). From this, we can see that H6 "patient satisfaction has a significant positive impact toward loyalty" is not supported, suggesting its effect to be fully mediated by affect patient trust and commitment. The contribution of patient trust on commitment. Patient trust has a significant positive impact on the commitment ( $\beta=0.635, \rho<0.05$ ). From this, we can see that $\mathrm{H} 7$ "patient trust has a significant positive impact toward commitment" is accepted. Thus, the higher the patient trust, the higher the patient commitment.

To further ascertain the effect of some variables on others, indirect effects were tested. The results are presented in Table 3 [58] indicates the importance of ascertaining these indirect effects. The results of testing the indirect effect can be explained: $\mathrm{H} 8$ is rejected, the indirect effect of service quality on patient loyalty, patient satisfaction mediated indicates that the application of a good service quality, real or not directly able to significantly increase patient loyalty is higher. The pattern of the relationship of service quality on patient satisfaction and patient satisfaction directly affect loyalty no relationship between service quality and patient loyalty, patient satisfaction in this study it is said to be fully mediated (complete mediation). H9 is accepted, the indirect effect of patient satisfaction on loyalty mediated by the belief that patients showed patient satisfaction can increase patient loyalty through higher patient trust. Pattern indirect relationship to patient loyalty, both significant, but testing direct influence between the variables of patient satisfaction on loyalty is not significant. Thus, the mediating role of patient trust can be complete mediation. H10 is accepted, the indirect effect of the variable patient satisfaction patient loyalty, mediated by the commitment of the patients showed that patient satisfaction can increase patient loyalty through higher patient commitment. Furthermore, the pattern of relationships indirect (mediation) in this study, the variable patient satisfaction to patient commitment and loyalty commitment directly to the patient, both significant, but the testing of direct influence between the variables of satisfaction with patient loyalty is not significant. This means that mediation patient commitment can be said to be complete mediation. Fourth indirect effect variable patient trust the loyalty of patients, which is mediated by the patient through a higher commitment. H11 the pattern of relationships indirect in this study, the variable patient trust and commitment to the patient's commitment to the patient directly to patient loyalty, both significant. Thus the role of mediation can be said to be the patient commitment partial mediation.

\section{Discussion}

Study results show a significant positive impact of service quality on patient satisfaction; hence, there is a significant relationship between service quality and satisfaction [3,6,7,8,47]. Patient satisfaction has a significant positive impact on trust, which is aligned with the view of [13] that the patient perception of satisfaction affects the level of trust given a service provider. Theory says that "to be loyal customers, good service or in line with expectations [5]. The theory of the service quality by [34] that there are two factors that affect the quality of services, the service to be expected, and services received. If the services received or perceived as expected consumers, the perceived service quality is good and satisfying. If the services received exceed consumer expectations, the quality of service perceived as ideal quality. But otherwise if the services received lower than expected, the perceived poor quality of services.

This study found that both the impact of patient satisfaction has a significant positive impact toward the trust $[14,15,52,64]$ and commitment $[12,28,29,31]$. However, in contrast to the findings of the research [29] expressed increased satisfaction and customer trust is not accompanied by an increase in higher customer commitment to restaurant customers. This aligns with previous findings of patient satisfaction having a 
significant positive impact on trust and commitment. Thus, patient satisfaction has a significant positive impact on relationship quality. Results show that the higher the relationship quality (patient trust and commitment), the higher the loyalty. This confirms previous findings that relationship quality (patient trust and commitment) has a significant positive impact on loyalty 12,14,28-33]. Therefore, relationship quality (patient trust and commitment) has a significant positive impact on patient loyalty. Further, Patient satisfaction no significant effect on loyalty is not supported, in contrast to the findings of the research [14,25]. Therefore, suggesting its effect to be fully mediated by affect patient trust and commitment. Patient trust has a significant positive impact toward commitment, the results extend the findings $[12,16,28]$. Thus, the higher the patient trust, the higher the patient commitment.

The full mediation is established because none of patient satisfaction has a direct significant relationship with patient loyalty, and both patient trust and commitment have a direct positive relationship with patient loyalty. A summary of the fully mediated model findings is shown in Table 3. Overall, in testing our hypothesized model shown in Figure 2, we found that patient trust and commitment fully mediate the relationships between patient satisfaction and patient loyalty. When examining the influence of each patient trust and commitment as mediators, we found that patient satisfaction, trust and commitment fully mediate the effect of patient satisfaction on loyalty. [52] define trust, trust as the perception of confidence in the exchange partner's reliability and integrity. [52] define commitment as: exchange partners believe that there is a relationship with others is essential to ensure maximum efforts to maintain it is, the party is committed relationship is worth working on believe ensuring that persist indefinitely that commitment as one of the two most important factors that determine the lasting relationships and loyalty. [40] that the trust customers have a positive and significant impact on a company have direct and positive impact on the consumers commitment to the company. The results extend and supported the findings by [12,16,28-32].

\section{Implications}

Theoretically, our research is the first that has examined the effect of service quality indicators on loyalty via patient satisfaction as an integrated model. This research has enriched our understanding of the service quality indicators (Tangibles, reliability, responsiveness, assurance, and empathy) that should be possessed by public hospital service who have a positive effect on patient satisfaction and later leads to achieve patient loyalty. From an international marketing perspective, our research is the first of its kind that is devoted to understanding service quality and patient loyalty through patient satisfaction, trust and commitment in emerging or developing countries public hospital environments, e.g. Indonesia. Finally, from the transactional marketing perspective, it is recognized that the marketing mix elements, either the 4Ps or the 7Ps, are very similar among public hospital service. Moreover, the research findings of the study contribute to the development of theories, especially theories of marketing management as follows the findings of this study prove that the model of the relationship between customer satisfaction and loyalty is more integrated with mediating variables include patient trust and commitment, which previous researchers test is performed separately. The results of this study, there are seven direct causal relationship and four indirectly referring to the theory and the results of several previous studies. The theory in question is the relationship marketing theory $[39,40,45]$, theory of service quality [34], theory of satisfaction (personal control theory) [39,40]. Loyalty theory [43] and the theory of relationship quality (trust and commitment) by [52].

The results from this research have implications for managers and decision makers in the public hospitals service sectors. Our results provide a framework for the managers hospitals to maintain patient satisfaction. It was found that availability of service quality is not sufficient for having patient satisfaction because patients perception of the service delivered affects their evaluation and eventually their level of satisfaction, with the intention of keeping the patient loyal, satisfied and to achieve excellent performances. In fierce competition, it is essential for the public hospitals to develop superior patients service skills and service capabilities that are able to satisfy and retain patient loyal. Finally, healthcare managers have to consider healthcare delivery as a network event rather than as an isolated encounter by involving patients' family/friends in the care. Managers can also focus on budget neutral approaches for the factors which have little or no impact on satisfaction.

\section{Limitations and future research}

A foundation for future work has been laid in this study. In addition to the valuable insights revealed through this study, there is an avenue for future research in the area of service quality, patient satisfaction, trust, commitment and patient loyalty, as well as the service quality gaps in public hospital management. In this study, all variables were measured at one point in time in this research, thus essentially from a static perspective. Given the emphasis on the practical application of data collection, dynamic relationship quality over time was not surveyed here. It is recommended that further interpretation of the findings for other circumstances should be made with caution. This condition is influenced by several factors that are not directly a limitation for 
researchers, namely the object of the study is limited to the perception of the patient, the health care services in the public hospital of Southeast Sulawesi, has not been included on the perception of the officer/medical personnel on service health and hospital management of Southeast Sulawesi province. Limited research examining patients at the public hospital of Southeast Sulawesi province, so the results of this study can't be generalized to hospitals in other areas.

Future studies may extend the study scope to include a larger sample. Differences in the perceptions of patients and their satisfaction levels could provide more insights into public hospital services in Southeast Sulawesi province. Future research could also attempt to investigate the influence of family and friends on patients, who are the primary customers of healthcare services. The current study has considered only the service receivers' perceptions. Future studies could gather data on hospital service providers' perceptions and arrive at a Gaps-Model for Southeast Sulawesi province hospitals. Moreover, the research could be enhanced by expanding the current model. The role of cultural issues could be investigated to add further depth to the model.

\section{Conclusion}

The major contribution to this study is the adoption of a more comprehensive approach to investigating determinants of loyalty than previous studies. The literature on the integrated relationships between service quality, satisfaction, trust, commitment and loyalty is quite rich but it is not the case when the construct's individual dimensions are taken into account. Thus, this study has a wider coverage of the key dimensions of service quality and their impact on satisfaction, trust, commitment and loyalty in hospitals settings. Patient trust and commitment can be considered as the key construct in hospital service performance. Therefore, offering high standards of service quality should be managed to increase patient loyalty, which in turn will result in a higher level of patient trust, leading to improved patient commitment. The results prove that the theory which says that the quality of service will affect the satisfaction and contentment will affect loyalty. For this study the object at the public hospital of Southeast Sulawesi was not proven. However, patient satisfaction would be better if, action and service systems performed well again, despite the fact that the patient satisfied with the quality of service, but does not guarantee patient loyalty. In addition, the results of the study proved that the theory that satisfaction will affect the trust and confidence will affect loyalty. In this study it was not proven, but loyalty will increase if the trust acts of service and service system performed better.

The research proves that the satisfaction affects commitment and commitment affect loyalty. In this study it was not proven. However, patient satisfaction would be better if the medical team and the patient has a strong commitment. In this study proved, that if the patient is high trust will affect the strong commitment and high impact on loyalty. Patient satisfaction results showed no significant effect on loyalty, to increase patient satisfaction then the hospital must prioritize what is needed at this time the patient improved services and service systems that exist today. For the management public hospital of Southeast Sulawesi Provincial is expected to improve the quality of service because of the results of the study respondents for all indicators are still low especially on indicators of empathy, where patients still feel a lack of attention, courtesy, friendliness shown by the medical team to the patient and the doctor is still a lack of awareness provide information about the development of the patient's illness. The results showed the trust variables important role in improving patient loyalty, for it is the management of the public hospital of Southeast Sulawesi province needs to maintain and enhance trust through actions better system services. In addition the research also shows the commitment variable role to increase the loyalty of the patients, the management of the General Hospital of Southeast Sulawesi province needs to maintain and enhance this commitment in a relationship at any time especially for patients in treatment. Finally beliefs affect patient loyalty through commitment to improving patient loyalty means patients need to increase the patient trust and commitment.

\section{References}

[1] Morrisson, O. and Huppertz, J.W. External equity, loyalty program membership, and service recovery, Journal of Services Marketing, 24(3), 2010, 244-54

[2] Michel, S. and Meuter, M.L. The service recovery paradox: true but overrated?, International Journal of Service Industry Management, 19(4), 2008, 441-57.

[3] Panchapakesan Padma, Chandrasekharan Rajendran, Prakash Sai Lokachari, Service quality and its impact on customer satisfaction in Indian hospitals: Perspectives of patients and their attendants. Benchmarking: An International Journal, 17(6), 2010,807 - 841

[4] Zeithaml, V.A. and Bitner, M.J, Service marketing: integrating customer focus across the firm, (3 ${ }^{\text {rd }}$ ed. McGraw-Hill, Boston, 2004).

[5] Kotler Philip and Keller Kevin Lane, Marketing Management, $\left(8^{\text {rd }}\right.$ ed. Perarson Prenntice Hall, 2006)

[6] Hu, H.-H., Kandampully, J. and Juwaheer, T.D. Relationships and impacts of service quality, perceived value, customer satisfaction, and image: an empirical study, The Service Industries Journal, 29(2), 2009, 111-25.

[7] Herington, C. and Weaven, S. E-retailing by banks: e-service quality and its importance to customer satisfaction, European Journal of Marketing, 43(9), 2009, 12-31.

[8] Mohamad, M. and Awang, Z. Building corporate image and securing student loyalty in the Malaysian higher learning industry, Journal of International Management Studies, 4(1), 2009, 30-40.

[9] Huang, E. and Liu, C.-C. A study on trust building and its derived value in C2C e-commerce, Journal of Global Business Management, 6(1), 2010, 186-95. 
[10] Kim, K.J., Jeong, I.-J., Park, J.-C., Park, Y.-J., Kim, C.-G. and Kim, T.-H. The impact of network service performance on customer satisfaction and loyalty: high-speed internet service case in Korea, Expert Systems with Applications, 32(3), 2007, 822-31.

[11] Shyh-Jane Li, Yu-Ying Huang, Miles M. Yang, (2011), How satisfaction modifies the strength of the influence of perceived service quality on behavioral intentions, Leadership in Health Services, 24(2), 2011,91 - 105

[12] Wei-Ming Ou, Chia-Mei Shih, Chin-Yuan Chen, Kuo-Chang Wang, Relationships among customer loyalty programs, service quality, relationship quality and loyalty: An empirical study, Chinese Management Studies, 5(2), 2011, 194-206

[13] Pierre Chenet, Tracey S. Dagger, Don O'Sullivan. Service quality, trust, commitment and service differentiation in business relationships, Journal of Services Marketing, 24(5), 2010, 336-346

[14] Norizan Kassim, Nor Asiah Abdullah, The effect of perceived service quality dimensions on customer satisfaction, trust, and loyalty in e-commerce settings: A cross cultural analysis, Asia Pacific Journal of Marketing and Logistics, 22(3), 2010, 351 - 371

[15] Norizan Mohd Kassim and Salaheldin Ismail. Investigating the complex drivers of loyalty in e-commerce settings. Measuring Business Excellence, 13(1), 2009, 56-71.

[16] Sunil Sahadev \& Keyoor Purani, Modelling the consequences of e-service quality. Marketing Intelligence, 26(6), 2008, 605-620.

[17] Ilias Santouridis, Panagiotis Trivellas, (2010), Investigating the impact of service quality and customer satisfaction on customer loyalty in mobile telephony in Greece, The TQM Journal, 22(3), 2010, 330-343

[18] Riadh Ladhari. Service quality, emotional satisfaction, and behavioural intentions A study in the hotel industry. Managing Service Quality, 19(3), 2009, 308-331

[19] Ioannis E. Chaniotakis, Constantine Lymperopoulos, Service quality effect on satisfaction and word of mouth in the health care industry, Managing Service Quality, 19(2), 2009, 229-242

[20] Tianxiang Sheng, Chunlin Liu, An empirical study on the effect of e-service quality on online customer satisfaction and loyalty, Nankai Business Review International, 1(3), 2010, 273-283

[21] Li-Wei Wu, Satisfaction, inertia, and customer loyalty in the varying levels of the zone of tolerance and alternative attractiveness, Journal of Services Marketing, 25(5), 2011, 310-322

[22] Hsin Chang and Hsin-Wei Wang. The moderating effect of customer perceived value on online shopping behavior. Online Information Review, 35(3), 2011, 333-359

[23] Amjad A. Abu-ELSamen, Mamoun N. Akroush, Fayez M. Al-Khawaldeh, Motteh S. Al-Shibly, Towards an integrated model of customer service skills and customer loyalty: The mediating role of customer satisfaction, International Journal of Commerce and Management, 21(4), 2011, $349-380$

[24] Thomas A. Brunner, Markus Stöcklin, Klaus Opwis, Satisfaction, image and loyalty: new versus experienced customers", European Journal of Marketing, 42(9), 2008, 1095 - 1105

[25] Aihie Osarenkhoe, Remedy or cure for service failure?: Effects of service recovery on customer satisfaction and loyalty, Business Process Management Journal, 18(1), 2012, 82 - 103

[26] Yongju Jeong, Yongsung Lee, A study on the customer satisfaction and customer loyalty of furniture purchaser in on-line shop, Asian Journal on Quality, 11(2), 2010, 146 - 156

[27] Birgit Leisen Pollack, Linking the hierarchical service quality model to customer satisfaction and loyalty, Journal of Services Marketing, 23(1), 2009, 42-50

[28] Ruben Chumpitaz Caceres and Nicholas G. Paparoidamis. Service quality, relationship satisfaction, trust, commitment and businessto-business loyalty. European Journal of Marketing, 41(7/8), 2007, 836-867.

[29] Dev Jani and Heesup Han. Investigating the key factors affecting behavioral intentions Evidence from a full-service restaurant setting. International Journal of Contemporary Hospitality Management, 23(7), 2011, 1000-1018

[30] Roland Kantsperger, Werner H. Kunz, Consumer trust in service companies: a multiple mediating analysis, Managing Service Quality, 20(1), 2010, 4-25

[31] Ki-Han Chung, Jae-Ik Shin, The antecedents and consequents of relationship quality in internet shopping, Asia Pacific Journal of Marketing and Logistics, 22(4), 4 2010, 473 - 491

[32] Irene Gil-Saura, Marta Frasquet-Deltoro and Amparo Cervera-Taulet. The value of B2B relationships. Industrial Management \& Data Systems Vol. 109 No. 5, 2009 pp. 593-609

[33] Tracey S. Dagger and Timothy K. O'Brien (2010). Does experience matter? Differences in relationship benefits, satisfaction, trust, commitment and loyalty for novice and experienced service users. European Journal of Marketing 44(9/10), 2010, 1528-1552.

[34] Parasuraman, A., Zeithaml, V.A. and Berry, L.L. SERVQUAL: a multiple-item scale for measuring consumer perceptions of service quality, Journal of Retailing, 64(1), 1988, 12-40.

[35] Cronin, J.J. and Taylor, S.A. Measuring service quality: re-examination and extension, Journal of Marketing, 56(3), 1992, 55-68.

[36] Bitner, M.J. Evaluating service encounters: the effects of physical surroundings and employee responses, Journal of Marketing, 54(2), 1990, 69-82.

[37] Parasuraman, A., Zeithaml, V.A. and Berry, L.L. (1985), "A conceptual model of service quality and its implications for future research", Journal of Marketing, 49(1), 1985), 41-50.

[38] Gronroos, C. An applied service marketing theory, European Journal of Marketing, 16(7), 1982, 30-41.

[38] Parasuraman, A., Zeithaml, V.A. and Berry, L.L. Refinement and reassessment of the SERVQUAL scale, Journal of Retailing, 67(4),1991, 420-45.

[39] Kotler, P, Marketing management, (The millenium edition. Upperb Sadlle River, Prentice-Hall International, Inc. 2000)

[40] Engel, James F., Roger D. Blackwell, and Paul W. Miniard, Perilaku Konsumen, (Jilid 1. Alih bahasa oleh FX Budiyanto, Binarupa Aksara, Jakarta, 1995)

[41] Collier, J.E. and Bienstock, C.C. Measuring service quality in e-retailing, Journal of Service Research, 8(3), 2006, 260-75.

[42] Noor Hazilah Abd Manaf, Phang Siew Nooi, Patient Satisfaction as an Indicator of Service Quality in Malaysian Public Hospitals, Asian Journal on Quality, 10(1), 1, 2009, 77-87

[43] Mohammad Ahmad Al-Hawari, Automated service quality as a predictor of customers' commitment: A practical study within the UAE retail banking context, Asia Pacific Journal of Marketing and Logistics, 23(3), 2011, 346 - 366.

[43] Oliver, R.L. A cognitive model of the antecedents and consequences of satisfaction decisions", Journal of Marketing Research, 17(4), 1980, 460-9.

[44] Natalisa, D. and Subroto, B. Effects of management commitment on service quality to increase customer satisfaction of domestic airlines in Indonesia, Singapore Management Review, 25(1), 1998, 85-105.

[45] Tjiptono, FandyPemasaran Jasa, (Edisi Pertama, Diterbitkan oleh Bayumedia Publishing. Malang-Jawa Timur, 2005)

[46] Michel Rod, Nicholas J. Ashill, Jinyi Shao, Janet Carruthers, An examination of the relationship between service quality dimensions, overall internet banking service quality and customer satisfaction: A New Zealand study, Marketing Intelligence \& Planning, 27(1), 2009, 103-126 
[47] Boshoff, C. and Gray, B. The relationships between service quality, customer satisfaction and buying intentions in the private hospital industry, South African Journal Business Management, 35(1), 2004, 27-38.

[48] Wu, W.Y., Hsiao, S.W. and Kuo, H.P. Fuzzy set theory based decision model for determining market position and developing strategy for hospital service quality, Total Quality Management, 15(1), 2004, 439-56.

[49] Ulaga, W. and Eggert, A. Relationship value and relationship quality: broadening the nomological network of business-to-business relationships, European Journal of Marketing, 40(3/4), 2006, 311-27.

[50] Athanasopoulou, P. Relationship quality: a critical literature review and research agenda, European Journal of Marketing, 43(5/6),2009, 583-610.

[51] Achim Walter, Thomas Ritter, The influence of adaptations, trust, and commitment on value-creating functions of customer relationships, Journal of Business \& Industrial Marketing, 18(4), 2003, 353-365

[52] Morgan, Robert M and Shelby Hunt. The Commitment-Trust Theory of Relationship Marketing. Journal of Marketing. 58(3), 1994, 20- 38.

[53] Marianne Horppu, Olli Kuivalainen, Anssi Tarkiainen, Hanna-Kaisa Ellonen, Online satisfaction, trust and loyalty, and the impact of the offline parent brand, Journal of Product \& Brand Management, 17(6), 2008, 403 - 413

[54] Cooper, D. R., dan Schindler, P. S., Business Research Methods. (Eight Edition. McGraw-Hill/Irwin, New York, 2003).

[55] Hair, Joseph F, William C. Black, Barry J. Babin, and Ronald L. Tatham, Multivariate Data Analysis. (Siventh Edition. Pearson Education, 2010)

[56] Malhorta, Naresh, Marketing Research, An Applid Orientantion. (Prentice-Hall. Inc., New Jersey. 2010).

[57] Sekaran, Uma. Research Methods for Business: A Skill Building Approach, (4 ${ }^{\text {ed }}$, John Willey \& Sons, York, 2006).

[58] Sobel, M.E. Direct and indirect effects in structural equation models, Sociological Methods and Research, 16(1), 1987, 155-76

[60] Hong Qin, Victor R. Prybutok. Service quality, customer satisfaction, and behavioral intentions in fast-food restaurants. International Journal of Quality and Service Sciences, 1(1), 2009, 78 - 95

[61] Jamal, A. and Anastasiadou, K. Investigating the effects of service quality dimensions and expertise on loyalty, European Journal of Marketing, 43(3/4), 2009, 398-420.

[62] Tracey S. Dagger, Meredith E. David, Sandy Ng, Do relationship benefits and maintenance drive commitment and loyalty?, Journal of Services Marketing, 25(4), 2011, 273-281

[63] Yung Shao Yeh, Yung-Ming Li, Building trust in m-commerce: contributions from quality and satisfaction, Online Information Review, 33(6), 2009, 1066-1086

[64] Gour C. Saha, Theingi, Service quality, satisfaction, and behavioural intentions: A study of low-cost airline carriers in Thailand, Managing Service Quality, 19(3), 2009, 350 - 372 